\title{
Misses the Sight of Saskatchewan Birds
}

Frank Rouse, Burnaby, B.C.

A FTER living in Saskatchewan for over forty years, most of it on the open prairie, I find it is not so easy to observe the birds in this district of Burnaby; the migration of birds is not as noticeable in the spring and fall, I miss the sight of the flocks of geese and ducks and the meadow larks singing their spring song, and the Baltimore Oriole. We have robins with us the year round, also Spotted Towhees and Song Sparrows, both varieties of which make godo use of our feed shelf throughout the winter. We have many Oregon .Juncos here through the winter months and a few varied Thrush when the ground is covered with snow.

I am told by Bird Watchers here that both of these varieties go to higher levels in the mountains for the summer. There are many varieties of ducks that winter along the coast a few miles from here. Ring-necked pheasants are quite common near here and the males have been busy crowing since early February. I saw a swallow for the first time this spring on April 5th.

I find each copy of "The Blue Jay" most interesting and appreciate the effort of all those who are responsible for the writing, assembly and printing of such good articles and am pleased I had the opportunity of being a subscriber since 1942 .

\section{Whooping Cranes Head North}

THE Whooping Cranes, America's most publicized birds, have left the Aransas National Wildlife Refuge in Texas to make the long flight to their unknown breeding grounds in the far north, the National Audubon Society reports. Last fall 25 Whooping Cranes arrived at the Aransas Refuge, but two of them subsequently died of gunshot wounds received en route. This indicates that the giant birds run their major risks while en route from the breeding to the wintering grounds.

An encouraging note on the Whooping Crane front is that five young birds were added to the ranks during the summer of 1951. The continental population of "whoopers," which includes the two birds at the Audubon Park Zoo in New Orleans, now stands at 25. Efforts to prevent the extinction of the Whooping Crane are jointly sponsored by the Fish and Wildlife Service and the National Audubon Society.

In days gone by when waterfowl were moulting and flightless, Indians staged "harvesting drives." . . . Thus did the tribes add to their stockpile of food against the long winter's and possible famine.

\section{Exhausted Bluebirds}

\section{Arthur Ward, Swift Current}

TT DOES not always require warm

days of sunshine or budding trees to stir the migratory instinct of some species. Even the Juncos and Sparrows, so prevalent in our experience as the forerunners of the northern trek were lacking in this respect.

Such was the case on the 17th of March. In the face of three days continuous snow and cold blustery weather there appeared four Bluebirds in Mr. Pearson's garden, Swift Current. They were in such an exhausted condition that John and Judy (twins of the family) just picked three of them up. The fourth, having more energy, struggled away. One of the captives succumbed to the ordeal; the other two were fed and after careful treatment, released on the 27th of March.

Having just returned from Saskatoon where I had the pleasure of showing bird pictures on the screen to our ardent naturalist Arnold MacPherson and Mr. H. E. Wood of the Nature Column in the Star-Phoenix, I went over to the Pearson's home hoping to band the two Bluebirds, only to find that they had already been released. 